\title{
Customer satisfaction towards Hyundai Car in Virudhunagar District
}

\author{
S. Karthik, R. Selvakumar
}

\begin{abstract}
The Indian automobile business became the fourth largest within the world. Hyundai is among the only a few automotive manufacturers to know the Indian automotive market well. It's the second largest automobile manufacturer with 16.2 percent market share in February 2019.Customer choice process is a complex phenomenon. Making a decision to buy a product or services involves many processes. The researcher has made an attempt to identify the brand preference of Hyundai cars in the study area and to examine customer satisfaction. This study includes the ways of getting awareness about Hyundai cars, the factors influencing the buying decision of the customers and the level of satisfaction towards these Hyundai cars. In order to analyze the level of satisfaction of customers towards Hyundai car, ranking method is used by calculating weighted average score for the each influencing factor. With regard to after sale service, interior decoration and Air cooler facility, the customers are dissatisfied with these factors. On the other positive side, Most of the customers are very much satisfied with the style/color, safety, engine performance and driving comfort.
\end{abstract}

Key words: Hyundai car, customer satisfaction, factors, After sales service.

\section{INTRODUCTION}

The Indian automobile business became the fourth largest within the world. The 2 wheelers phase dominates the market in terms of volume due to a growing class and a young population. The auto exporter has robust export growth expectations for the close to future. The key automobile players within the Asian nation market area unit are expected to create India a pacesetter within the 2 wheeler and 4 wheeler market in the world by 2020 .

Hyundai is among the only a few automotive manufacturers to know the Indian automotive market well. It's the second largest automobile manufacturer with 16.2 percent market share in February 2019. Accordingly, global market research firm JD power reported that Hyundai motor India has flat- topped the after sales customer satisfaction survey among mass market brands. Hyundai, the country's second largest automotive merchandiser, scored the highest 912 points in after sales customer satisfaction survey.

Brand plays a vital role in market segmentation and it attracts the user mind in buying luxuries goods. Currently, customers face a growing varies of alternative within the product and service. They will obtain on their basis of

Revised Manuscript Received on December 09, 2019.

S. Karthik,*Assistant Professor, Department of Commerce, Kalasalingam Academy of Research and Education, Krishnan Koil, Virudhunagar Dist,Tamilnadu E-mail id: karthik.s@klu.ac.in

R. Selvakumar, Assistant Professor, Department of Commerce, Kalasalingam Academy of Research and Education, Krishnan Koil, Virudhunagar Dist, Tamilnadu E-mail id: selvakumar.r@klu.ac.in alternative and perception of quality worth and service firms have to be compelled to perceive the determination of customer value and satisfaction customer delivered value is that distinction between total customer value and total customer cost.

\section{STATEMENT OF THE PROBLEM}

Customer choice process is a complex phenomenon. Making a decision to buy a product or services involves many processes. The literature on brand preference studies reveals that for the selection of durable products, especially four wheelers, the customer has to spend much time to evaluate and choose the preferred one, based on their necessity and financial condition. The marketing strategies followed by the manufacturer and marketer as well as pre-conceived idea of the buyer also play a vital role in selection of a particular brand and to get more satisfied. Only a limited number of attempts have been made to study the impact of brand preference factors on customer's satisfaction. So the researcher has made an attempt to identify the brand preference of Hyundai cars in the study area and to examine customer satisfaction.

\section{REVIEW OF LITERATURE}

Dr. V.K.K Kaushik and NeerajKaushik (2005) in their study on Brand Preference and Recommendations on Various Cars. The result of the study Hyundai and maruthi dominates market of the region. Purchasing of car influenced by friends, family and relatives rather than by dealer and sales persons. Most of the consumers are happy with its performance, quality, sales service, dealer network and they are recommending to others also. The primary determinant for buying cars in this region based on brand name, fuel efficiency and price.

Dr. A.T. Jaganathan, Mr. M. Mohanraj (2015) in their present to study the brand preference of customers with regard to Hyundai. The result of this study reveals that level of satisfaction and the overall performance of the Hyundai cars are good. The study has suggested that the advertisers need to focus on their market assuming the influence of the television advertisement in the Hyundai purchase behavior.

Dr. V. Suganthi (2016) study made an attempt to understand the factors influencing buying decision of the customer. Most of the customers are satisfied with the Mileage and fuel efficiency of the car and they preferred Maruti Suzuki Swift. 


\section{OBJECTIVES OF THE STUDY}

- To know the customer awareness towards various brands and models of Hyundai cars

- To analyze the factors influencing the buying decision of Customers and identify the level of Customer Satisfaction towards buying of Hyundai cars.

\section{RESEARCH METHODOLOGY}

The type of research used is exploratory research. Primary Data is collected from the users of Hyundai car in Virudhunagar District through questionnaire method. Secondary data is collected from the previous project reports, magazine, journal etc., In this study, researcher has used convenient sampling method. The sample unit selected for the research is 400 Hyundai car users in Virudhunagar District. The researcher has used tools for the analysis like percentage and weight average method.

\section{RESULTS AND DISCUSSION}

The following are the analysis and interpretation

\subsection{GENDER WISE CLASSIFICATION OF THE RESPONDENTS}

Table 1

Gender wise Classification

\begin{tabular}{|l|l|l|l|}
\hline S.NO & Gender & $\begin{array}{l}\text { No. of } \\
\text { Respondents }\end{array}$ & Percentage \\
\hline 1 & Male & 346 & 87 \\
\hline 2 & Female & 54 & 13 \\
\hline & Total & $\mathbf{4 0 0}$ & $\mathbf{1 0 0}$ \\
\hline
\end{tabular}

Source: Primary Data

Table 1 shows that gender of the respondents. Out of 400 respondents, $346(87 \%$ ) respondents are male and remaining are female $(13 \%)$. It is inferred from the table that majority of $(87 \%)$ respondents are Male users.

\subsection{AGE WISE CLASSIFICATION}

Table 2

Age wise classification

\begin{tabular}{|l|l|l|l|}
\hline S.No & Age & $\begin{array}{l}\text { No. of } \\
\text { Respondents }\end{array}$ & Percentage \\
\hline 1 & Below 30 & 115 & 29 \\
\hline 2 & $30-40$ & 109 & 27 \\
\hline 3 & $40-50$ & 126 & 32 \\
\hline 4 & Above 50 & 50 & 12 \\
\hline & Total & $\mathbf{4 0 0}$ & $\mathbf{1 0 0}$ \\
\hline
\end{tabular}

Source: Primary Data

The above table 2 shows that $29 \%$ of respondents are belonging to the age category of below 30 years, $27 \%$ of respondents are come under the age group of 30- 40 years, $32 \%$ of respondents fall between the age group of $40-50$ years and the remaining $12 \%$ of respondents are belonging to the age group of above 50 . It is clear from the above table that most $(\mathbf{2 9 \%})$ of the respondents are falling in the age group of below 30 years.

\subsection{INCOME LEVEL OF THE RESPONDENTS}

Table 3

Income of the Respondents

\begin{tabular}{|l|l|l|l|}
\hline S.No. & $\begin{array}{l}\text { Income } \\
\text { (Annum) }\end{array}$ & $\begin{array}{l}\text { No. of } \\
\text { Respondents }\end{array}$ & $\begin{array}{l}\text { Percenta } \\
\text { ge }\end{array}$ \\
\hline 1 & Up to 4 lakhs & 100 & 25 \\
\hline 2 & $\begin{array}{l}\text { 4 lakhs to 6 } \\
\text { lakhs }\end{array}$ & 194 & 49 \\
\hline 3 & $\begin{array}{l}\text { 6 lakhs to } 8 \\
\text { lakhs }\end{array}$ & 106 & 26 \\
\hline & Total & $\mathbf{4 0 0}$ & $\mathbf{1 0 0}$ \\
\hline
\end{tabular}

Source: Primary Data

It is clear from the Table 3 that $25 \%$ of the respondents earned income up to 4 lakhs, $49 \%$ of the respondents falls under the income group between 4 lakhs to 6 lakhs and $26 \%$ of the respondents earned income between 6 lakhs to 8 lakhs. Hence, it is inferred that Most $(49 \%)$ of the respondent's income lies between 4 lakhs to 6 lakhs.

6.4 MODEL OF THE CAR OWNED BY THE RESPONDENTS

Table 4

Model of the car owned by the Respondents

\begin{tabular}{|l|l|l|l|}
\hline S.No & Models & $\begin{array}{l}\text { No. of } \\
\text { Respondents }\end{array}$ & Percentage \\
\hline 1 & Elantra & 62 & 15.5 \\
\hline 2 & i10 & 48 & 12 \\
\hline 3 & Santa Fe & 64 & 16 \\
\hline 4 & Xcent & 36 & 9 \\
\hline 5 & Tucson & 74 & 18.5 \\
\hline 6 & Eon & 28 & 7 \\
\hline 7 & i20 Active & 50 & 12.5 \\
\hline 8 & Verna & 38 & 9.5 \\
\hline $\begin{array}{l}\text { Total No. of } \\
\text { Respondents }\end{array}$ & $\mathbf{4 0 0}$ & $\mathbf{1 0 0}$ \\
\hline
\end{tabular}

Source: Primary Data

Table 4 shows that respondents owned car models, it is clear that most of the respondents $(18.5 \%)$ have owned Tucson model car brand. $16 \%$ of them have purchased Santa Fe model. $15.5 \%$ of them have purchased Elantra model. $12.5 \%$ and $12 \%$ of them have possessed i20 Active and i10 model of car. $9.5 \%, 9 \%$ and $7 \%$ of them bought Verna, Xcent and Eon types of Hyundai cars. Finally it is concluded that most $(\mathbf{1 8 . 5 \%})$ of the respondents have purchased Tucson model.

\subsection{AWARENESS OF HYUNDAI CARS}

Table 5

Awareness of Hyundai cars

\begin{tabular}{|l|l|l|l|}
\hline $\begin{array}{l}\text { S. } \\
\text { No }\end{array}$ & Awareness & Frequency & Percentage \\
\hline 1 & Television & 108 & 27 \\
\hline 2 & Friends & 84 & 21 \\
\hline 3 & Family Members & 46 & 11.5 \\
\hline 4 & Advertisement & 162 & 40.5 \\
\hline & Total & $\mathbf{4 0 0}$ & $\mathbf{1 0 0}$ \\
\hline
\end{tabular}

Source: Primary Data 
Table 5 shows that the awareness of the Hyundai cars. Out of 400 respondents, 27 percent (108) of the respondents know about the car through television, 21 percent (84) of the respondents collected information about the brand through friends, 11.5(46) percent of the respondents are aware from family members, 40.5 percent(162) of the respondents gathered knowledge though advertisement. Thus, most $(\mathbf{4 0 . 5 \%})$ of the respondents are aware on Hyundai brand through advertisement.

\subsection{FEATURES ATTRACTED THE RESPONDENTS} Table 6

Features that attracted the respondents

\begin{tabular}{|c|c|c|c|}
\hline $\begin{array}{c}\text { S. } \\
\text { No }\end{array}$ & Features & $\begin{array}{c}\text { No. of } \\
\text { Respondents }\end{array}$ & Percentage \\
\hline 1 & Price & 56 & 14 \\
\hline 2 & Mileage & 284 & 71 \\
\hline 3 & Service & 40 & 10 \\
\hline 4 & $\begin{array}{c}\text { Brand } \\
\text { image }\end{array}$ & 20 & 5 \\
\hline & Total & 400 & 100 \\
\hline
\end{tabular}

Source: Primary Data

From the above table, it is concluded that Out of 400 respondents, $71 \%$ of them say that mileage is crucial and attracted by mileage of the car. $14 \%$ of them opined that the price is the influencing factor in purchasing the car. and $10 \%$ \& $5 \%$ of them say service and brand image are attracted in buying car. Thus majority (71\%) of the respondents opined that mileage is important feature of Hyundai car model.

\subsection{MAIN REASONS FOR BUYING HYUNDAI CARS}

Table 7

Main reasons for buying Hyundai Cars

\begin{tabular}{|c|c|c|c|}
\hline S. No & $\begin{array}{l}\text { Reasons for } \\
\text { buying } \\
\text { Maruti }\end{array}$ & $\begin{array}{l}\text { No. of } \\
\text { Respondents }\end{array}$ & Percentage \\
\hline 1 & $\begin{array}{ll}\text { Suits } & \text { my } \\
\text { needs } & \\
\end{array}$ & 36 & 9 \\
\hline 2 & $\begin{array}{l}\text { Easy } \\
\text { maintenance }\end{array}$ & 84 & 21 \\
\hline 3 & $\begin{array}{l}\text { Suitable for } \\
\text { Indian roads }\end{array}$ & 228 & 57 \\
\hline 4 & Trust worthy & 20 & 5 \\
\hline \multirow[t]{2}{*}{5} & Fuel efficient & 32 & 8 \\
\hline & Total & 400 & 100 \\
\hline
\end{tabular}

Source: Primary Data

The table 7 shows that reasons that specified by the respondents for buying Hyundai car. 57\% of the respondents buying for hyundai, it's good for Indian road condition. $42 \%$ of respondents says that easy maintenance of car, $9 \% \& 8 \%$ of the respondents say that suits their needs and fuel efficient. It is concluded that majority $(57 \%)$ of the respondents told that Hyundai car is suitable for Indian roads.

\subsection{FACTOR AFFECTING BUYING BEHAVIOUR OF RESPONDENTS}

Table 8

Respondents of factor affecting buying behaviour

\begin{tabular}{|l|c|c|c|c|c|c|c|c|}
\hline $\begin{array}{l}\text { Factors affecting } \\
\text { buying behavior }\end{array}$ & HS & S & Neut & DS & HDS & Total & $\begin{array}{l}\text { Weighted } \\
\text { score }\end{array}$ & Rank \\
\hline Safety & 144 & 136 & 80 & 40 & 0 & 1584 & 3.96 & 4 \\
\hline $\begin{array}{l}\text { Engine } \\
\text { Performance }\end{array}$ & 200 & 96 & 64 & 40 & 0 & 1656 & 4.14 & 3 \\
\hline Driving comfort & 180 & 116 & 88 & 16 & 0 & 1660 & 4.15 & 2 \\
\hline Service & 44 & 72 & 112 & 140 & 32 & 1156 & 2.89 & 6 \\
\hline $\begin{array}{l}\text { Interior } \\
\text { decoration }\end{array}$ & 60 & 36 & 104 & 176 & 24 & 1032 & 2.58 & 7 \\
\hline Air cooler & 32 & 48 & 98 & 168 & 44 & 1026 & 2.56 & 8 \\
\hline Style/colour & 200 & 160 & 0 & 40 & 0 & 1720 & 4.3 & 1 \\
\hline Resale value & 120 & 100 & 144 & 24 & 12 & 1492 & 3.73 & 5 \\
\hline Total
\end{tabular}

Source: Primary Data

HS- Highly satisfied, S- Satisfied, Neut-Neutral, DS-Dis satisfied, HDS-Highly Dissatisfied

Table 8 shows that weighted average scores of factors affecting buying behavior through customer satisfactions. Among various level of satisfaction towards the Hyundai car, style/ colur has ranked $1^{\text {st }}$ with average score of 4.3. Next driving car and engine performance have ranked $2^{\text {nd }}$ and $3^{\text {rd }}$ with average score of 4.15 and 4.14 respectively. Remaining factors safety, resale value, after service, interior decoration and air cooler have ranked fourth and so on. The customer is not much bothered about interior decoration and air cooler. Finally it is concluded that the customers are very much satisfied because of style/clour, driving comfort and engine performance.

\section{SUGGESTIONS}

1.In this study, majority of the respondents are dominated by Male group and very few female having own car. To attract female consumer, the car mechanism has to change and driving system to be automated.

2. Majority of the customers felt that the after sale service provided by the company is not up to the mark. Hence, the service offered to the customer should be improved by way of providing adequate information and offers regular repairs and maintenance service without any delay.

3.With regard to interior decoration of car, majority of the customers opined that they are dissatisfied and ranked the last position by the customers. Some of them are neutralized with their opinion towards these services. In order to increase interior decoration of car may be added accessories, protecting steering wheel, dashboard, protecting seat covers, increase the storage space etc.,

4. Majority of the customers dissatisfied with the facility of Air cooler of car and ranked as the last position. Hence, the company should increase the efficiency of the Air cooler facility by quick absorbing heat. Use window shades, sun visors, vent the interiors, $\mathrm{A} / \mathrm{c}$ curtain are few ways to improve efficiency of air cooler. 


\section{CONCLUSION}

Hyundai is one of the most preferred brands by majority of the customers. The present study also has fulfilled all the objectives. The study has helps to find out important factors which influence buying behavior Hyundai car. In order to improve the production and sales operation the Hyundai car manufactures has to follow the above said suggestions. Most of customers are very much satisfied with regard to style/color, safety, engine performance and driving comfort.

\section{SCOPE FOR FURTHER STUDIES}

The same study has to conduct other brands of cars within area or beyond area in India. So far all companies are concentrated only cities and towns. There is an opportunity to conduct the same in rural area also. This will helpful for growing rural market in India.

\section{REFERENCE}

1.Dr. V.K.K Kaushik and NeerajKaushik [south west Haryana], "A Study on Brand Preference and Recommendation on Various Cars". Indian Journal of Marking, Vol xxxv, No.4 April 2005.

2. Dr.A.T.Jaganathan, Mr.M.Mohanraj,"A STUDY ON BRAND AWARENESS TOWARDS HYUNDAI CARS IN TAMILNADU, Journal Mechanical and Civil Engineering, Volume-2, Issue-6 , June2015, pg 32-41

3. Dr. V. Suganthi, R. Renuka . A study on customer satisfaction towards Maruti Suzuki Swift cars in UdumalpetTaluk International Journal of Multidisciplinary Research and Development feb -2016-ISSN: 2349-4182.

\section{AUTHORS PROFILE}

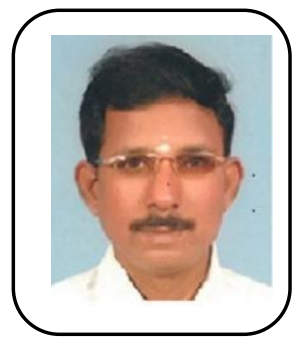

Dr.S.Karthik has completed M.Com., MPhil., Ph.D SET., PGDCA.,MBA. He has presented 54 papers in National and International level. He has published 26 Articles in International and National Journals including Scopus indexed Journals. He has guided M.com projects and Ph.D project. He received Life time Member in Teaching and Education Research Association (TERA), Social Science and Humanities Research Association (SSHRA) and IRDP group of journals. He has also received three awards Best Teacher award 2013, Teaching Excellence award 2018 and Life time Teaching and Research Excellence award 2019.

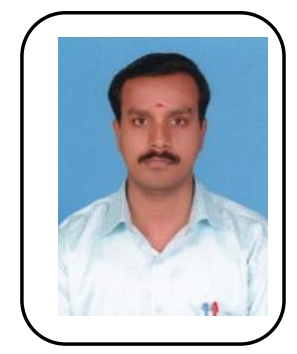

Dr.R.Selvakumar has completed M.Com. MPhil., Ph.D SET., PGDCA.,. He has presented 57 papers in National and International level. He has published 41 Articles in International and National Journals including Scopus indexed Journals. He has guided M.com projects. He received Life time Member in Teaching and Education Research Association (TERA), Social Science and Humanities Research Association (SSHRA) and IRDP group of journals. He has also received two awards Teaching Excellence award 2018 and Teaching and Research Excellence award 2019. 